\title{
Maimonides as a Physician
}

By J.Z.Baruch

It is the followers of Nestor, a Greek priest and monk from the fifth century, who during their missionary activities in the Middle East also carried Greek medicine from Greece to the East. There the Arabs, who as it were surged out of the desert under the victorious banners of Islam, came into contact with Greek medicine. The medical works of Hippocrates and Galen were translated into Arabic along with the philosophical writings of Plato and Aristotle. Greek science blended with Oriental wisdom. The Arabs developed a rich literature, art and science of their own. In the Arab world medicine reached a high degree of development, at any rate a higher development than medicine was at first to reach in Europe.

In the second half of the eighth century the Arab world was divided by a schism. The Eastern caliphate of the Abassids came into being, Baghdad being the centre. The Western caliphate of the Umayads was to develop with Cordova as its capital. This schism in the Arab world was also to manifest itself in philosophy and medicine. The Eastern school got figures like Rhazes and Avicenna as leaders, while the Western caliphate got under the influence of Avenzoar and Averroes.

With the decline of both caliphates the seat of study and science of the Arab world moved to Egypt, then under the enlightened rule of the Ayyubites. It was in this period that one of the most celebrated physicians of the Middle Ages, Moses ben Maimon, came to Egypt and there made his important contribution to the medical science. He embodied the best in Arabic medicine of both the East and West caliphates and considerably contributed to the spread of the knowledge of Arab medicine in Europe. Moses ben Maimon is commonly referred to as Maimonides or as Rambam, which is the composition of the initials of Rabbi Moses ben Maimon.

Maimonides was born in Cordova, the seat of the Western Caliphate, on March 30, 1135. His father was a judge. We know only little of the early life and education of Maimonides, but judging by his many later writings he, already in his youth, was thoroughly tutored in such sciences as mathematics, astronomy, astrology, medicine, philosophy and theology, while he also profoundly studied the bible and the postbiblical important Jewish literature such as Mishnah and Talmud. Throughout Maimonides' later life it was 
shown that he found the study of the Jewish writings most important. He regarded the study of the bible as the basis of any further scientific development. It is not quite clear where Maimonides acquired his knowledge of medicine, but it is beyond doubt that he gained his basic knowledge of medicine in the Western caliphate. In one of his medical writings "The Regimen of Health" he states, in discussing a certain prescription: "This is what we have received from the Elders of the Art" (According to the English translation by Bar Sela [1964] from Arabic). In his treatise on accidents he states: "Thus we have seen the outstanding Elders do in the land of Andalusia", but he does not mention these Elders by name. (According to the English translation by Bar Sela (1964) from Arabic). In his book on asthma he records an incident involving the scholar Ibn Zuhr, as Avenzoar was named, who lived in Spain. But he states at the same time that he gained his knowledge of the question involving Ibn Zuhr from the latter's son Abū Bakr, whom he knew well. In 1148 Cordova, along with the rest of Moorish Spain, was conquered by the al-Muw'ahhidin (Almohades), a sect of unitarian Moslem zealots.

An era of religious intolerance and persecution ensued: the Jews were given the choice of conversion to Islam or exile.

Maimonides' father and his family chose exile. They left Cordova and first went to Fez in Morocco. There they had no peace either and in 1165 they left Fez and migrated to the Holy Land. A plate in the port of Acco in present-day Israel still mentions the place where Maimonides and his family entered the Holy Land.

But in the Holy Land they were not left alone either, thus the family left for Egypt, where they arrived during 1165. Maimondies' father had died in the meantime. Maimonides and his brother David settled in Fustāt (Old Cairo). As a merchant David supported the whole family, while Maimonides devoted all his time to study. He had already published treatises on the Jewish Calendar and on Logic, but in 1168 he wrote commentaries on the Mishnah, the 6-volume collection of laws, regulations and legends, which, further to the Bible, had been prepared about 225 . These commentaries on the Mishnah gave Maimonides a great reputation throughout the Jewish world.

David, Maimonides' brother, perished in the Indian Ocean, thus Maimonides had to earn a livelihood for his own family and that of his brother. For reasons of principle he refused to accept any remuneration for his rabbinical duties. He decided to earn a living through that branch of science that, just 
as theology, he knew quite well: medicine. As a physician he became famous in the court of the Sultan of Egypt and soon he was appointed court physician by Sultan Saladin of Egypt. At the same time Saladin appointed him Nagīd, i.e. spiritual leader of the Jewish community of Egypt. From now onwards Maimonides was to live in two spheres: he was the spiritual leader of Egyptian Jewry and personal physician and medical adviser of the Sultan and his court.

Ibn Tibbon was a friend of Maimonides', who had translated many of his works from the Arabic originals into Hebrew. In a letter addressed to him Maimonides describes his daily work as follows (according to the Dutch translation by Reisel from Arabic): "I live in Fustāt (old Cairo). The Sultan lives in Cairo. There ist a distance of about two kilometers between the two places. I have to visit the Sultan every day. This journey is difficult to me. I come in the mornings. If he does not feel well, one of his sons or one of his harem women appears ill, I am in the palace for the most part of the day ..."

"Coming home, I see many people in the passages, Jews and non-Jews of high and low social status; judges, inspectors, people that appreciate each other and people that do not like each other. A motley crowd. All of them know when I can be back. I get off my riding animal, wash my hands and go to them to reassure them and apologise for keeping them waiting a while until I have taken some food. (N.B.: As an orthodox Jew Maimonides refused to eat in the palace of the sultan.) Then I try to help them as a physician. I give them instructions for treating their diseases. Until midnight other patients are coming. Sometimes until two o'clock at night or even later! I speak to them, giving them instructions. Then I lay down for a while because of fatigue. When night falls I am so exhausted that I can hardly speak. All this shows that I can receive nobody for Jewish affairs at another time than shabbat. A great part of the Jewish community come on that day. After prayer I give a lead in preparation of the working days ..." In spite of his above-mentioned busy working days, largely devoted to medicine, Maimonides continued his religious and philosophical studies. In 1180, he published his major religious work, the Mishneh Torah, i. e. the repetition of the Torah (Pentateuchos). This important work consists of fourteen volumes. In these fourteen volumes Maimonides systematically reviews all laws, customs and regulations, found in the so called "Sea of the Talmud". It should be remembered that the Talmud is as it were the written reflection of the discussions that had been held in the Jewish schools for some successive centuries, until about 500 . There is hardly any subject but it can be found 
back somewhere in the Talmud, because during the centuries this subject was raised for discussion by one of the many scholars giving their opinion in the Talmud. The pros and cons of certain Jewish traditions are discussed in the Talmud, but often suddenly interrupted by some saga or legend, which somebody included in the discussion or simply suddenly recalled as a recollection. Traditions handed down are discussed and alternated with customs of a more recent date. Thus the Talmud is in no way a systematic, well arranged whole. Maimonides produced order out of this enumeration of genuine traditional conceptions, recent additions, and mixture of Wahrheit und Dichtung. His Mishne Torah inter alia deals with the Jewish holy and fast days. The Jewish regulations "on marriage" are discussed in one of the fourteen volumes of the Mishne Torah, while again other volumes are devoted to the regulations on administration of justice, the temple service, indemnities, and so on. The book begins with a description of the right relationship to God and fellow-being, the delimitation of Jewry in respect of other religions and the possibility, after erring, to return to fellow-being and Good.

"However, the book of Maimonides is no dry compilation or codification. It situates the behavioural standards within the framework of Jewish philosophy and conception of life and tries to make the readers judge then by their value" (N. Reisel).

In 1190, Maimonides wrote another work, "The Guide to the Perplexed". In this book he tries to reconcile Jewish thought and Aristotelian philosophy. This important philosophical main work of Maimonides was to be studied by Christian scholastics as well as by Jewish and Muhammedan scholars for many centuries after his death.

Maimonides devoted the last period of his life particularly to medical writing. He was familiar with the medical literature of the ancient Greek and Romans, while he had also thoroughly studied the writings of Arabic physicians. It is noticeable that Maimonides who, for the sake of his compilation and codification of the Talmud, had extensively and repeatedly studied the "Sea of the Talmud", ignores the various medical considerations and observations which, as a matter of fact, are met in the Talmud as well. $\mathrm{He}$, as a physician, apparently preferred the medical science as understood by Hippocrates and Galen. Yet he did not merely echo the views and directions of these lustrous medical predecessors. He was and remained critical, also in respect of these old masters of medicine. He combined theory and practice of the Greek and Roman physicians of before his time with more recent views and experiences of himself and others. 
His encyclopaedic knowledge of theology, philosophy and medical science renders his medical writings, too, a source of religious inspiration and of respect for God, the Creator of man. But, conversely, his religiousphilosophical works also show that as a philosopher too he remained the physician.

In his above-mentioned Mishne Torah Maimonides states (according to the English translation by Bar Sela (1964) from Hebrew): "Whereas by keeping the body in sound health one walks in the ways of God, for a man knows not nor understands when ill, a man must remove himself away from those things that destroy the body."

The authenticity of some of the works attributed to Maimonides is open to question. The so called "Daily Prayer of a Physician", often attributed to Maimonides, contains thoughts that originate or could originate from him, without it being quite clear that the authorship of this "Daily Prayer" as such belongs to Maimonides. However, this does not diminish his merits as author of various medical writings. At any rate there is consensus of opinion about the authorship of Maimonides of the following medical works:

1. A book on extracts from the works of Galen.

This is a carefully selected collection compiled from the various works of Galen. It is known in Arabic only; there are no Hebrew or Latin translations, contrary to many other medical works of Maimonides.

2. The Medical Aphorisms of Moses (Maimonides).

This book, composed between 1187 and 1190, was perhaps the most popular medical book of Maimonides, because in many European libraries there are versions in Arabic as well as in Hebrew and Latin. The Latin translation entitled Aphorismi Secundum Doctrinam Galeni was done by John de Capua towards the end of the thirteenth century. The book contains 1,500 aphorisms, most of which are drawn from Galen. 87 books of Galen were quoted in these aphorisms. In addition, Maimonides quotes several Arab authors in this book, among them Ibn Zuhr, venerated by him.

Maimonides added his own comments to the book, showing his own views. The whole book is classified into 25 chapters. Chapter 24 deals with rare phenomena, while the last chapter is devoted to the author's criticism of Galen's views and his doubt of many of the latter's statements. 
3. A Commentary on the Aphorisms of Hippocrates.

This book, divided into 7 chapters, contains Maimonides' commentaries on the Arabic translation of the aphorisms of Hippocrates. It was translated into Hebrew in the thirteenth century, but a Latin translation is not known.

4. On coitus.

Two treatises on sexual hygiene and aphrodisiac remedies are attributed to Maimonides. They were written at the request of people of nobility. No Hebrew or Latin translations of this work are known.

5. On Hemorrhoids.

A short treatise on hemorrhoids, written by Maimonides in 1187 at the request of a young nobleman. The book was translated into Hebrew, Latin and Spanish.

6. A discourse on Asthma.

In this book Maimonides treats not only the somatic aspects of asthma, but at the same time he gives hints and advice in the psychomatic field. It was written about 1190 . The following quotations from the treatise on Asthma have been taken from the English translation from Arabic by Muntner (1963).

Maimonides states clearly that "asthma has many etiological aspects and should be treated according to the various causes that bring it about" ... and ... "the success of relieving the patient from asthma depends largely on an intimate knowledge of the total patient". He also says that "he has no magic cure to report".

The book on asthma contains instructions covering hygiene, diet, medication, travel and personal behaviour for the son and successor of Sultan Saladin of Egypt whose asthma was initiated by common cold and rhinitis. The symptoms of hypersensitivity to common cold also occurred separately and distinctly from the asthmatic attacks.

The Prince, who lived in Alexandria, found he could tide over an asthmatic attack more quickly and easily by going to Cairo. Maimonides attributed this favourable response to the cleaner air in Cairo as contrasted to the contaminated air of densely populated Alexandria.

Maimonides stressed the significance of emotional factors in asthma. $\mathrm{He}$ remarks, interestingly, that dietary measures are to be taken in all disorders marked by "seizures", such as inflammation of the joints, migraine and asthma. Maimonides recognises the importance of here- 
dity, since he refers to the "bodily organs weak from birth" (I. Münz: Die jüdischen Ärzte im Mittelalter. Frankfurt a. M. 1922).

Maimonides advocated early treatment for the asthmatic patient. $\mathrm{He}$ outlines the danger of complications and incurable asthma. He noted that when a patient did not respond well to the initial scheme of treatment, he searched for multiple causes. Maimonides writes on the influence of air and psychic mood, he points to the importance of cold, humidity and extreme dryness. He considers all of them very harmful. He notes that mental suffering impairs physical well-being and adversely affects the respiratory organs. He gives philosophers and psychologists their due by outlining their important role in understanding the psychic condition of the patient.

M. Reisel: Maimonides. Kruseman, Den Haag, 1963: "Only diet and medical treatment cannot cure this disease." This view of Maimonides corresponds with his starting point that we must know the "total patient" to cure him. He states that "sleep during an attack may be dangerous". Nowadays this reminds us of the danger of overdosing an asthma patient to such an extent as to suppress the respiratory centre in the brain. He recommends to avoid excessive bathing as well as abrupt changes in temperature. Maimonides gives clear instructions regarding the diet. For example, he recommends that the patient should not use fermented cheese, onions or garlic, mutton, duck, goose, fatty foods, salty fish, the cabbage family, melons, peaches, grapes or dates.

Maimonides speaks of preventive measures such as "care for the cleansing of the lungs", because "every organ as a rule does away with bad residue when it regains its normal mixture". His drugs were meant to make the sputum liquid and dischargeable with ease. Maimonides preferred a single drug to using various drugs, but the drug should be based "on authoritative sources". He recommended enemas and certain herbs "to dry out any humidity in the head". By this he refers not only to the draining of "juices from the brain" but also to the discharge of mucus from nose and throat.

The treatment was intended to clear the lungs from moisture, to ease respiration and banish the cough. "Of all remedies there are no more perilous than blood-letting and purgatives; next come emetics and strong enemas" (M. Reisel: Maimonides).

Yet strong drugs may be useful if prescribed for individual cases by a physician at the right time. Maimonides followed the views of Hippo- 
crates, Galen and El-Razi, but he selected what was useful in his opinion. He spoke of the modern doctors in terms of those discarding the lessons of the past. He clearly recognised the clinical relation between natural resistance and diseases. When resistance is higher, there is no disease and no need for drugs, and conversely. Maimonides dwells on the psychological motivation of the true physician and warns against the bad physician and the term "experience" extensively used by ill-trained and ignorant physicians. In his opinion the study of medicine must consist of a combination of theory and practice. He often repeats that "the physician should not treat the disease, but the patient suffering from it" (G. Weil: Maimonides «Über die Lebensdauer». S. Karger, Bâle/New York 1953).

Maimonides found it correct to consult specialists, if necessary, because "they help each other to reach the desired end. Thus the best medical treatment is ensured by the advice of the collegium. He wrote: "Medicine is a science essential to man, always and everywhere, not only in times of illness but also in times of health. It can be truly said that medicine should accompany human beings permanently. The views of medicine may be derived only from those of a physician with a complete mastery of the theoretical and practical knowledge, so that one can safely lodge oneself in his hands. Both body and soul can be guided by his directions. Such physicians are found in all countries and in all times. "Further he states: "The clever, skilled physician who is familiar with the fundamentals of medicine and thinks twice before deciding how to relieve a patient, such a man always relies on the work of nature and prevents her from going lazy."

7. A book on Poisons and the Protection against Lethal Drugs.

At the request of the vizier al-Fadil, Maimonides, in 1198 wrote a book on organic and anorganic poisons, their toxicity, their antidotes, their treatment and also the treatment in emergency cases, e.g. after snake bite.

The book was translated into Hebrew by Ibn Tibbon and into Latin by John de Capua already mentioned. The book contains many useful suggestions, especially for the inhabitants of countries like Egypt where there is a frequent occurrence of poisonous snakes and other animals whose bites are harmful to humans.

8. A commentary on the Names of Drugs.

This book contains the names of 2,000 drugs, divided into 405 para- 
graphs. The drug names are given in Arabic, Greek, Persian, Berber and Spanish. Short descriptions and definitions are given of the action of the drugs, accompanied by Maimonides' comments on their application.

9. On the Regimen of Health.

This book was written for the son of sultan Saladin. It was composed in the years from 1193 to 1198 . The following quotations from "On the Regimen of Health" have been taken from the English translation (1964) from Arabic by Bar Sela. According to Maimonides this work is intended "to set forth rules that are easy to follow, and which are of great value in the regimen of health". Maimonides follows Hippocrates, who is alleged to have stated "that the conservation of health lies in abstaining from repletion and that one should not neglect exercise".

According to Maimonides: "Repletion requires filling the stomach to the utmost of its capacity, and distending it. When any organ becomes distended, its connections are loosened and its vigour is necessarily weakened. The stomach will in no wise digest such a meal adequately; indolence, feebleness of movement and heaviness of the meal will occur, and even more so when much water is drunk after the satiating meal. Therefore, serious indigestion will occur after such overburdening of the stomach. It may even lead to death ... If the food is badly digested in the stomach it will be poorly digested in the liver too. The third digestion (the first in the stomach, the second through the liver) will also be bad, which may cause various diseases."

In this connection Galen stated: "He who wants to avoid diseases should take care to avoid indigestion and should not move about after the meal." "Therefore", thus condudes Maimonides, "all physicians recommend that one should not eat until one is satiated. One should avoid overfilling, thus distension of the stomach."

"Nothing is better than exercise, because in exercise the natural heat flames up and all the superfluities are expelled, while at rest the flame of the natural heat subsides and superfluities are engendered in the body, even though the food is of the very best quality and is moderate in quantity. However, not all motions can be called exercise ... Exercise means vigorous motion whereby one breathes deeply and moves more quickly than usual ... But excessive exercise must be avoided ..."

10. On accidents.

In the first place Maimonides dwells on the theological backgrounds of accidents. Are accidents caused directly by God or do other factors, does 
chance also play a role or is there no chance at all but is everything, also the slightest accident, predestined by God? He recommends a drink made, according to Galen's recipe, from honey and white wine in the same way, he says, "as in ancient times oxymel was prepared from vinegar and honey."

He says: "Hydromel can also be prepared from sugar and wine." In his final section he apologises for the fact that he advised the vizier, for whom he wrote this book, to use wine. The fact is that Islam forbids the use of wine. "But", says Maimonides, "I have only mentioned what Medicine has taught to me." The lawgivers do know, as do the physicians, that wine may be for the benefit of mankind. The physician, because he is a physician, must give advice on the way how to behave during illness or after an accident, whether it is contrary to the law or is deemed permissible by the law (here the Koran is meant). The sick person must decide himself whether or not to follow the advice of the physician. If the physician neglects to mention all that is for the benefit of the patient, he, the physician fails as a physician. He must mention what may be for the benefit of his patient, whether it is forbidden by religious laws or deemed permissible...

If the doctor does not do this he deceives his patient and does not give a correct advice. It is clear that the religious laws command what is of benefit and prohibit what is harmful to the soul in the next world. The difference between the edicts of the religious laws and the counsels of medicine is that the laws command obedience to what benefits in the next world, while medicine prescribes what is useful and healthy and warns against what is harmful in this world, but does not compel this or punish for that. It leaves the matter to the sick in the form of consultation and it is they who have to choose ... This treatise on accidents has rather the form of consultation in connection with a special case. There is only an Arabic text.

Maimonides died in 1204. He was buried in Tiberias on the Lake of Tiberias, also known as the Lake of Galilee. His simple tomb has two hollows on either side. In the evenings women come to place bottles of oil into the hollows, and the next day they take these bottles away ... So great is still the name and fame of Maimonides as a physician that there are still people who believe that he, centuries after his death, can change their ordinary oil into curative oil ... 


\section{Literature}

Bar Sela, A., H.E.Hoff and E.Faris (1964), "Moses Maimonides", two treatises on the Regimen of Health. Transaction of the American Philosophical Society. New series, vol.54, part 4.

Chavel, CH.B. (1967), The commandments. Sefer Ha-Mitzvoth of Maimonides. Soncino Press, London.

Gladstone Bratton, F. (1967), Maimonides, medieval modernist. Beacon Press, Boston.

Muntner, S. (1963), Treatise on asthma. J. B. Lippincott Comp., Philadelphia, Montreal.

Münz, I. (1922), Die jüdischen Ärzte im Mittelalter. J. Kaufmann Verlag, Frankfurt a. M.

Reisel, M. (1963), Maimonides. Kruseman, Den Haag.

Weil, G. (1953), Maimonides «Über die Lebensdauer». S. Karger, Basel/New York.

\section{Summary}

The author describes live and work of Maimonides, mentions his non-medical writings and discusses his medical writings in detail.

\section{Zusammenfassung}

Der Autor beschreibt Leben und Wirksamkeit des Maimonides, erwähnt kurz seine nichtmedizinischen Schriften und stellt dann ausführlich seine medizinischen Werke vor.

Dr.J.Z.Baruch

Gerrit van der Veenstraat 141

1077 DX Amsterdam-Z 